\title{
PRODUKSI KESEMEK NON-ASTRIGENSI DENGAN PERLAKUAN HOT WATER TREATMENT DAN APLIKASI KOH
}

\author{
Rozana dan Lorine Tantalu \\ Dosen pengajar Program Studi Teknologi Industri Pertanian \\ Universitas Tribhuwana Tunggadewi Malang; rozanatunggadewi@gmail.com
}

\begin{abstract}
The treatment that is often used by farmers and persimmon collectors for local consumption in Indonesia is by immersion in quicklime (building lime) so as to produce powdery persimmon fruit that covers the color of mature persimmon fruit which is usually bright yellow to orange. This study aims to obtain the best treatment to produce persimmon according to the quality requirements desired by consumers through $\mathrm{KOH}$ application treatment to obtain bright and attractive colors, Hot Water Treatment (HWT) for relieving soreness and disinfecting pests, and soaking in lime solution to maintain texture fruit. The experimental design of this study was Factorial Randomized Group Design with 2 factors, namely the immersion time of hot water 46 $O C(H W T)$ and $\mathrm{KOH}$ application. The first factor has three levels of treatment, namely without HWT (A1), 5 minutes (A2), and 10 minutes (A3). The second factor has two levels, namely without applying (B1) and applying $\mathrm{KOH}(B 2)$. Quality observations include measurements of weight loss, color, hardness, and total dissolved solids. The 5-minute HWT treatment and KOH application gave a significant effect on several parameters, namely weight loss, hardness, and total dissolved solids but were unable to extend the shelf life of persimmon.
\end{abstract}

Keywords: kesemek, $\mathrm{HWT}, \mathrm{KOH}$

\section{PENDAHULUAN}

Buah kesemek tua di pohon dari kultivar astrigen akan berasa sepat. Rasa sepat tersebut akan berkurang atau hilang tatkala buah telah menjadi matang dan lunak di pohon., atau telah mendapatkan perlakuan pascapanen. Padahal beberapa persyaratan mutu yang harus selalu dipenuhi oleh produsen buah kesemek adalah penampilan buah menarik, tekstur keras, manis, serta tanpa rasa sepat (Baraswati, et al ., 2006).
Adanya kandungan tanin dalam buah menyebabkan buah kesemek memiliki rasa sepat. Konversi tanin dari bentuk larut ke tidak larut selama pematangan buah di pohon akan mengurangi rasa sepat buah kesemek. Selain itu, pengurangan rasa sepat buah dapat juga dilakukan pada perlakuan pascapanen.

Perlakuan yang sering digunakan petani maupun pengumpul buah kesemek untuk konsumsi lokal di Indonesia adalah dengan perendaman dalam kapur tohor 
(kapur bangunan) sehingga menghasilkan buah kesemek berbedak sehingga menutupi warna buah kesemek matang yang biasanya berwarna kuning cerah sampai jingga. Begitu juga dengan perlakuan air hangat yang dapat menghilangkan rasa sepat tetapi menyebabkan penurunan mutu buah kesemek. Sehingga diperlukan perlakuan yang mudah diterapkan tetapi bisa menghasilkan buah kesemek yang bersih (tidak berbedak), renyah, manis, tidak sepat, warna menarik serta selama transportasi buah tidak mudah rusak. Oleh karena itu penelitian ini bertujuan memperoleh perlakuan terbaik untuk menghasilkan buah kesemek sesuai persyaratan mutu yang dikehendaki konsumen melalui perlakuan pengolesan $\mathrm{KOH}$ untuk memperoleh warna yang cerah dan menarik, Hot Water Treatment (HWT) untuk menghilangkan rasa sepat dan disinfestasi hama, dan perendaman dalam larutan kapur untuk mempertahankan tekstur buah.

\section{MATERI DAN METODE}

\section{Tempat dan Waktu}

Penelitian dilaksanakan di Laboratorium Rekayasa Proses Fakultas Pertanian, Universitas Tribhuwana Tunggadewi. Pelaksanaan penelitian dimulai pada bulan Mei hingga Juni 2018.

\section{Bahan dan Alat}

Bahan utama yang digunakan dalam penelitian ini adalah buah kesemek varietas astrinjen dari Kota Batu, Jawa Timur yang dipanen pada stadia matang komersial (kulit buah berwarna hijau kekuning-kuningan) serta tidak terdapat luka. Bahan lain yang digunakan adalah $\mathrm{KOH}$ dan $\mathrm{CaCl}_{2}$ yang diperoleh dari toko bahan kimia, aquades dan air panas dari Laboratorium Rekayasa Proses Unitri, serta bahan penunjang analisi lainnya.

Peralatan dalam penelitian ini meliputi water bath, chromameter (Minolta CR200), refractometer model N-1 Atago, rheometer tipe CR-300DX dan peralatan penunjang lainnya.

\section{Rancangan Penelitian}

Rancangan percobaan yang digunakan adalah Rancangan Acak Kelompok Faktorial dengan 2 faktor. Faktor pertama adalah lama perendaman air panas $46{ }^{\circ} \mathrm{C}$, (HWT) memiliki tiga taraf perlakuan yaitu tanpa HWT (A1), 5 menit (A2), dan 10 menit (A3). Faktor kedua adalah pengolesan $\mathrm{KOH}$ dengan dua taraf yaitu tanpa pengolesan (B1) dan pengolesan $\mathrm{KOH}$ (B2). Perlakuan ini diulang sebanyak 3 kali ulangan sehingga diperoleh 18 unit percobaan. Pengamatan yang dilakukan meliputi pengukuran susut bobot, warna, kekerasan, total padatan terlarut.

Data hasil pengukuran akan dilakukan analisis data menggunakan Analysis of Varian (ANOVA), jika menunjukan beda nyata maka dilajutkan dengan BNT dengan tingkat kesalahan 5\% (Gomez dan Gomez, 1995).

HASIL DAN PEMBAHASAN

\section{Susut Bobot}


Berdasarkan hasil pengamatan selama 15 hari penelitian, diperoleh pesentase rata-rata susut bobot kesemek pada berbagai perlakuan (Gambar 1). Persentase susut tertinggi terdapat pada perlakuan HWT 10 menit tanpa pengolesan $\mathrm{KOH}$, dan persentase susut bobot terendah terdapat pada perlakuan Non HWT dan non $\mathrm{KOH}$ (kontrol).

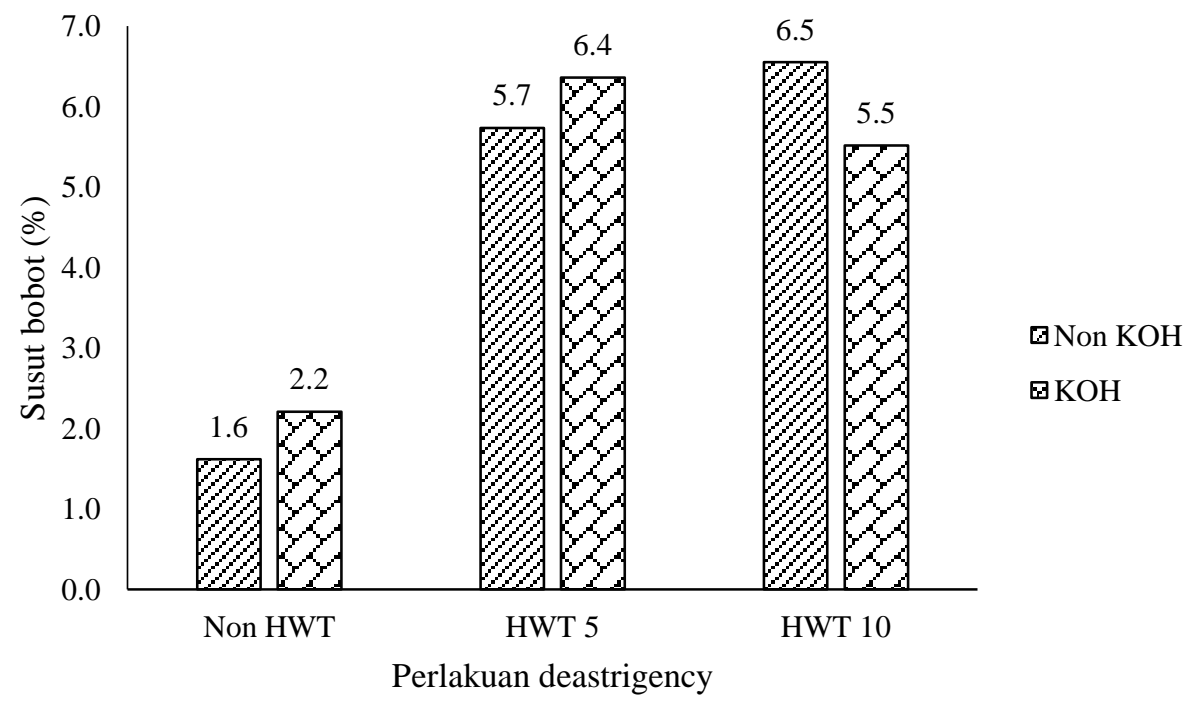

Gambar 1. Persentase Rata-rata Susut Bobot Buah Kesemek

Hasil analisis sidik ragam juga merupakan akibat pencelupan $\mathrm{CaCl} 2$. menunjukkan bahwa ada pengaruh Peningkatan susut bobot kesemek selama perlakuan terhadap susut bobot kesemek. penyimpanan juga disebabkan adanya Proses respirasi dan transpirasi pada komoditas hortikultura mengakibatkan berkurangnya cadangan makanan dan air sehingga terjadi susut bobot pada komoditas tersebut seiring dengan lama penyimpanan. Menurut Ahmad (2013), karbohidrat, protein, lemak, dan zat gizi lainnya dirombak menjadi zat-zat yang lebih sederhana selama proses respirasi, sehingga susut bobot akan semakin meningkat. Penurunan susut bobot juga daat disebabkan oleh terurainya glukosa selama proses respirasi (Pantastico, 1986). kerusakan buah berupa bintik-bintuk dan retakan pada kulit buah kesemek yang memicu pertumbuhan jamur dan meningkatkan laju respirasi buah, sehingga terjadi peningkatan susut bobot.

\section{Kekerasan}

Pengukuran kekerasan dapat dilakukan secara kualitatif dengan indera perasa maupun secara kuantitatif dengan alat rheometer. Hasil pengamatan kekerasan pada buah kesemek disajikan pada Gambar 2.

Besarnya persentase susut bobot yang terjadi pada perlakuan HWT dan $\mathrm{KOH}$ 


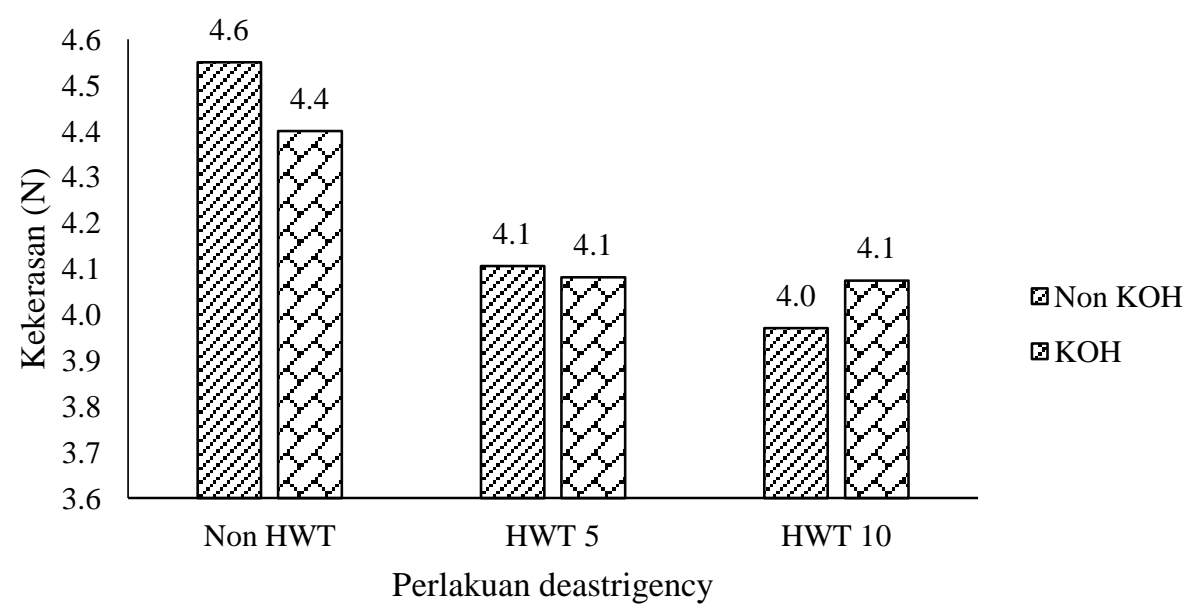

Gambar 2. Rata-rata Kekerasan Buah Kesemek

Pada Gambar 2 dapat dilihat bahwa kekerasan buah kesemek menurun dengan adanya perlakuan HWT dan $\mathrm{KOH}$. Hasil analisis sidik ragam menunjukkan bahwa perlakuan HWT dan $\mathrm{KOH}$ tidak berpengaruh terhadap kekerasan selama penyimpanan.

Hasil uji BNT pada taraf $\alpha<0.05$ memperlihatkan bahwa, pencelupan buah air panas (HWT) tidak mampu mempertahankan kekerasan buah, sebaliknya justru menurunkan kekerasan buah. Buah tanpa diberi perlakuan HWT dan $\mathrm{KOH}$ memiliki nilai kekerasan paling tinggi. Hal ini serupa dengan penelitian ChávezSánchez et al. (2013) pada buah pepaya yang menyatakan bahwa perlakuan AHWT pada suhu $55^{\circ} \mathrm{C}$ selama $0,3,6$, dan 9 menit pada suhu penyimpanan $25{ }^{0} \mathrm{C}$ tidak berpengaruh nyata terhadap kekerasan.

Pelunakan buah selama penyimpanan merupakan akibat adanya proses perombakan protopektin menjadi pektin yang larut air. Jumlah protopektin akan berkurang seiring pematangan buah sehingga buah mejadi lunak (Winarno 2002; Fajriyati 2010).

Pecahnya jaringan pada buah sehingga menjadi lunak adalah akibat pemecahan karbohidrat menjadi senyawa yang sederhana karena proses respirasi dan transpirasi. Pada proses respirasi terjadi degradasi hemiselulosa dan pektin dari dinding sel, sedangkan pada proses transpirasi air dalam buah akan menguap menyebabkan pelayuan dan mengkerut lunak (Syahfutri 2006).

\section{Warna}

Variasi hasil pengukuran warna $\left(\mathrm{L}^{*}\right.$, $a^{*}$, dan $\left.b^{*}\right)$ dan derajat warna $\left({ }^{\circ}\right.$ Hue $)$ pada buah kesemek ditampilkan pada Tabel 1. Hasil menunjukkan bahwa skor L keenam sampel terdapat pada subset yang berbeda sehingga dapat dikatakan terdapat perbedaan kecerahan pada sampel kesemek. 
Tabel 1. Nilai L, a, b, dan Hue buah kesemek

\begin{tabular}{lccccc}
\hline \multicolumn{1}{c}{ Perlakuan } & L & a & b & ${ }^{\mathbf{0}}$ Hue & Warna \\
\hline Non HWT, Non KOH & 73.2 & 73.8 & 5.8 & 74.0 & Yellow red \\
Non HWT, KOH & 67.8 & 77.7 & 12.0 & 78.6 & Yellow red \\
HWT 5, Non KOH & 64.7 & 77.7 & 10.4 & 72.7 & Yellow red \\
HWT 5, KOH & 65.6 & 73.7 & 10.9 & 74.5 & Yellow red \\
HWT 10, Non KOH & 66.0 & 75.6 & 10.8 & 76.3 & Yellow red \\
HWT 10, KOH & 70.0 & 69.1 & 69.4 & 98.0 & Yellow \\
\hline
\end{tabular}

Nilai $\mathrm{a}^{*}$ (redness) skor positif $\mathrm{a}^{*}$ paling tinggi dimiliki oleh perlakuan non HWT dan $\mathrm{KOH}$ yang menunjukkan bahwa sampel memiliki warna merah dengan intensitas yang tinggi.

\section{Nilai b* (yellowness) tertinggi} dimiliki oleh HWT 10 dan $\mathrm{KOH}$. Berdasarkan hasil analisis diketahui bahwa non HWT 5 dan non $\mathrm{KOH}$ berwarna paling merah disusul HWT 5 dan $\mathrm{KOH}$. Hasil uji warna ini menguatkan hasil analisis sensori deskriptif yang menjelaskan bahwa kesemek pada umumnya memiliki intensitas warna jingga yang tinggi.

Hue merupakan warna spektrum yang dominan sesuai panjang gelombang yang dihasilkan. Warna kuning-jingga yang terdapat pada kesemek dikarenakan adanya pigmen dari karotenoid. Hal ini terjadi pula pada buah mangga. Awalnya butiran granula dan dan osmiofilik tertata rapi pada kloroplas dari sel buah mangga yang belum matang. Kemudian membran granula kehilangan isinya selama pematangan dan munculnya globula osmiofilik yang menunjukkan perubahan kloroplas menjadi kromoplas yang mengandung pigmen karoten merah atau kuning. Lebih dari 50\% total karotenoid terdiri dari $\beta$-karoten. Perbedaan varietas dan spesies mempengaruhi fraksi karoten pada buah sehingga warna buah pun berbeda (Mitra 1997).

\section{Tingkat kemulusan kulit buah}

Perlakuan perendaman dalam air panas (HWT) baik 5 menit maupun 10 menit dan diikuti dengan pengolesan $\mathrm{KOH}$ memberikan pengaruh pada kulit buah kesemek baik warna maupun kemulusan. Persentase kemulusan kulit buah kesemek disajikan pada Tabel 2.

Persentase terendah terdapat pada perlakuan HWT 10 menit dan non $\mathrm{KOH}$. Lama perendaman dalam air panas mengakibatkan kulit luar buah kesemek mengalami retak dan terbakar. Hal ini disebebkan panas pada air menyebabkan kerusakan jaringan pada kulit buah kesemek. Perlakuan kontrol (non HWT dan non $\mathrm{KOH}$ ) memberikan nilai tingkat kemulusan tertinggi, hanya saja kulit kesemek tersebut terlihat keriput dan mengkerut. Pengkerutan terjadi karena jumlah air yang keluar dari 
kulit buah kesemek lebih tinggi dibanding perlakuan lainnya.

Tabel 2. Persentase tingkat kemulisan kulit buah kesemek

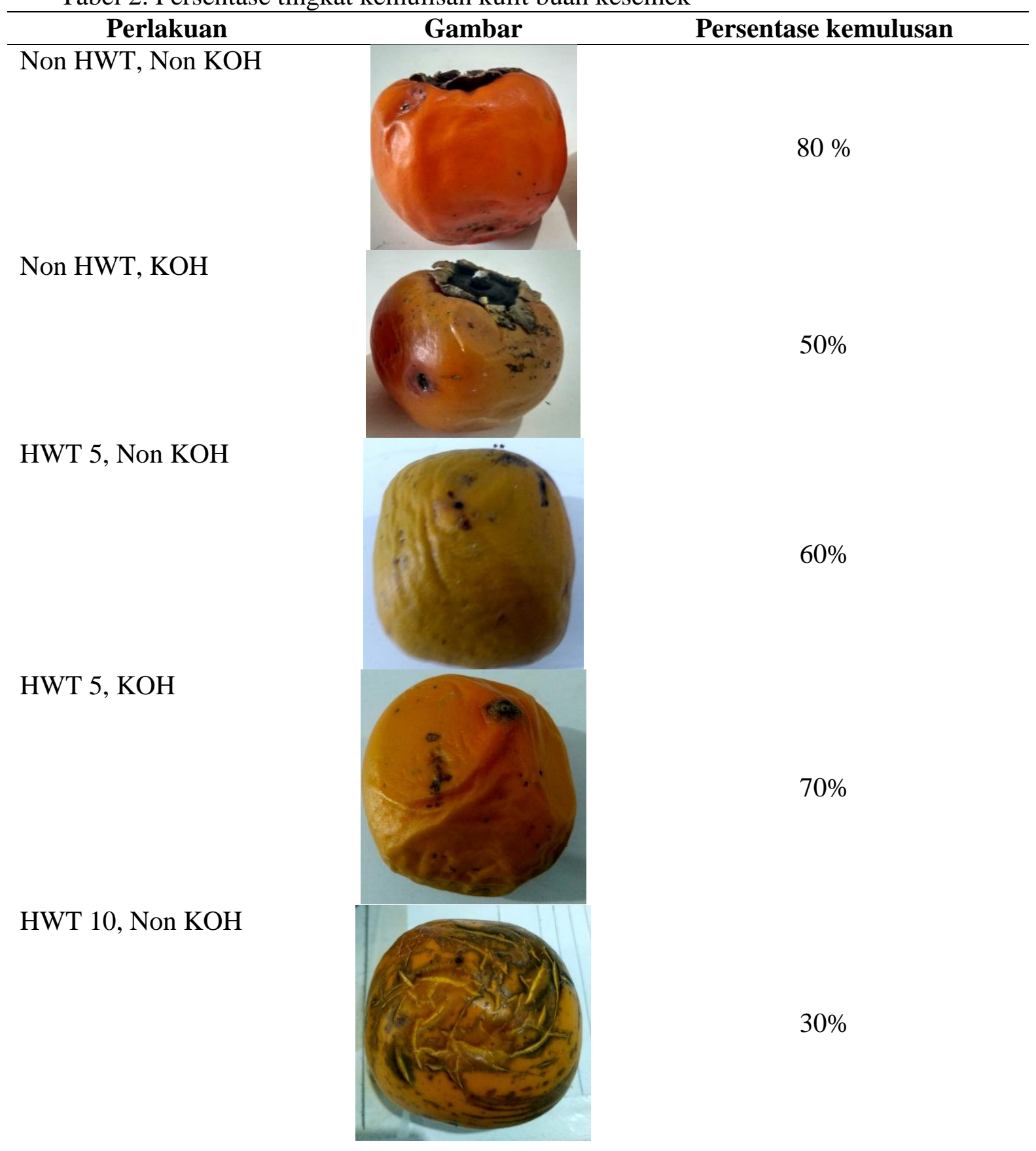


HWT 10, KOH

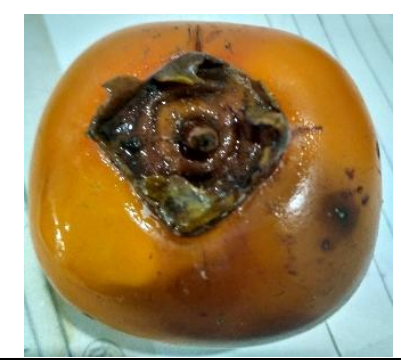

$40 \%$

\section{Total Padatan Terlarut}

Total padatan terlarut pada buah kesemek yang diberi perlakuan HWT 10 menit dan pengolesan $\mathrm{KOH}$ mencapai 18.5 ${ }^{\circ}$ Brix. Sedangkan kesemek tanpa perlakuan HWT dan $\mathrm{KOH}$ berkisar antara 15.3-15.6 ${ }^{\circ}$ Brix (Gambar 3).

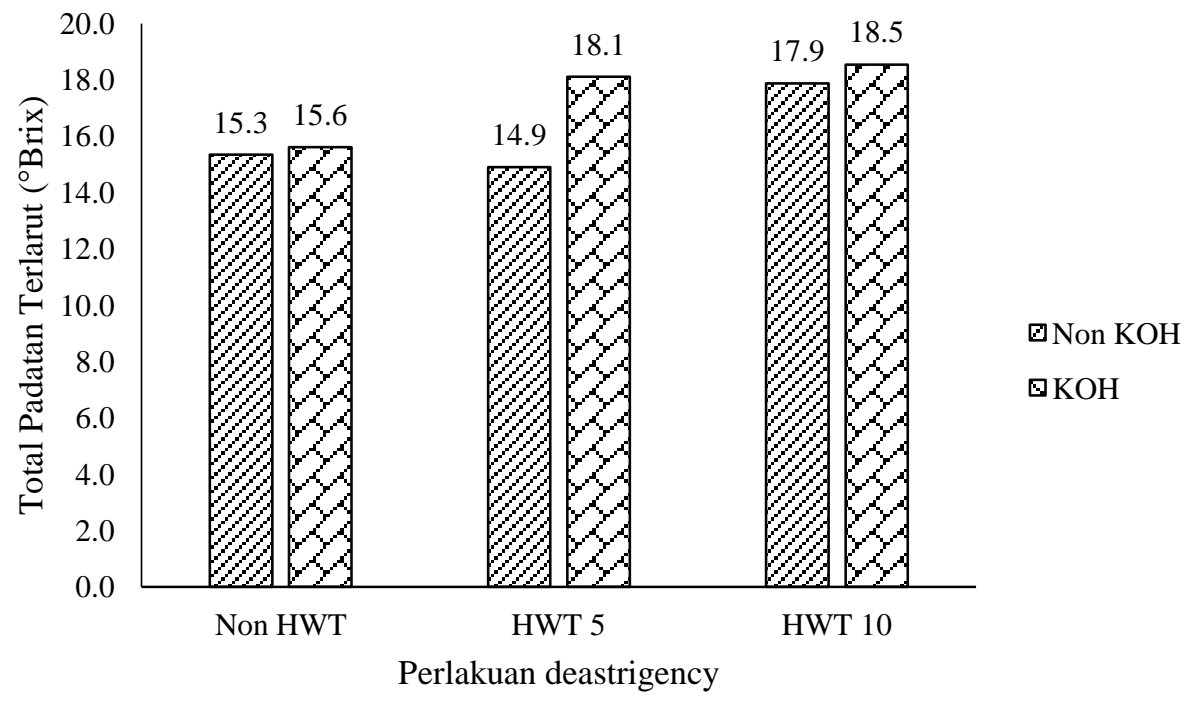

Hasil analisis sidik ragam menunjukkan bahwa perlakuan HWT dan $\mathrm{KOH}$ memberikan pengaruh nyata terhadat TPT buah kesemek. Berdasarkan Gambar 3 dapat dijelaskan bahwa tingkat kemanisan yang tinggi bearti buah kesemek tersebut sudah matang dan kandungan gula pada buah cukup tinggi.

Testoni (2002) melaporkan bahwa kandungan gula yang dominan pada buah kesemek adalah fruktosa dan glukosa yang mencapai $90 \%$ dengan perbandingan 1:1. 
segera memproduksi ethylene hingga beberapa hari. Sehingga perlu perlakuan tambahan atau buatan untuk merangsang produksi ethylene pada buah kesemek setelah dipanen. Untuk menghilangkan sifat astrigensi pada buah kesemek biasanya dilakukan dengan pemberian gas CO2 (Toye, 1987), atau penyemprotan alkohol (ethanol) sesudah panen (Kato, 1990). Dengan penyemprotan ethanol maka buah kesemek akan menjadi lebih lunak, mempunyai rasa manis dan tekstur yang bagus dalam waktu 10-14 hari.

Kato (1990) menyatakan secara ekonomis pemberian gas $\mathrm{CO} 2$ umum diterapkan secara komersial pada produksi buah kesemek di Jepang dari pada penyemprotan dengan ethanol karena waktunya lebih pendek yaitu 1-3 hari dan bisa dikembangkan secara komersial dengan kuantitas lebih besar. Untuk penerapan perbaikan kualitas buah kesemek di Indonesia penyemprotan menggunakan alkohol atau ethanol lebih memungkinkan dengan alasan lebih sederhana dan bisa diterapkan secara individu petani atau skala kecil.

Jika memakai pemeraman gas $\mathrm{CO} 2$ di Indonesia biayanya lebih mahal karena perlu membangun ruang khusus untuk pengaliran gas tersebut. Jika produksi buah kesemek di Indonesia besar tidak menutup kemungkinan pemeraman gas $\mathrm{CO} 2$ juga akan berkembang karena penampilan buah yang bagus akan menarik konsumen.

\section{KESIMPULAN DAN SARAN}

\section{Kesimpulan}

Dari hasil penelitian dapat disimpulkan bahwa perlakuan HWT dan $\mathrm{KOH}$ memberikan pengaruh nyata terhadap beberapa parameter yaitu susut bobot, kekerasan, dan total padatan terlarut akan tetapi tidak mampu memperpanjang umur simpan buah kesemek.

\section{Saran}

Perlu dilakukan penelitian kesemek dengan perlakuan HWT dan $\mathrm{KOH}$ berdasarkan tingkat kematangan buah kesemek.

\section{DAFTAR PUSTAKA}

Anonim. 2012 Okt. Memanfaatkan Potensi

Buah Indonesia. Komunika. Beranda : Edisi 20 tahun ke VII.

Crisosto, C.H., 1999. Persimmon Postharvest Quality Maintenance Guidelines. Pomology Department. University of California, http://www.uckac.edu/ postharv/PDF\%20files/Guidelines/ persimmon.pdf.

Besadaa C, Richard C. J, Shane O, Allan B. W. 2010. Response of Fuyu persimmons to ethylene exposure before and during storage. Journal Postharvest Biology and Technology 57. 124-131 p.

Brackmann, A., de Freitas, S.T., Pinto, J.A.V., 2004. Ripening control with 1- methylciclopropene on 'Fuyu' persimmon in cold storage and controlled atmosphere. Rev. Fac. Zootec. Vet. Agro. Uruguaiana 11, 123-134 p.

Chávez-Sánchez, I., A. Carillo-Lopez, M. VegaGarcia, E.M. Yahia. 2013. 
The effect of antifungal hot-water treatments on papaya postharvest quality and activity of pectinmethylesterase and polygalacturonase. Food $\mathrm{Sci}$ Technol. 50(1):101- 107.

Del Bubba. M , E. Giordani, L. Pippucci, A. Cincinelli, L. Checchini, P. Galvan. 2009. Changes in tanins, ascorbic acid and sugar content in astringent persimmons during ontree growth and ripening and in response to different postharvest treatments. Journal of Food Composition and Analysis 22. 668$677 \mathrm{p}$.

FAOSTAT, 2007. Retrieved June 2, 2008 from: http://faostat.fao.org.

Hardenburg, R.E., et al. 1986. The Commercial Storage of Fruits, Vegetables, and Florist and Nursery Stocks. USDA Agriculture Handbook 66. 130 pp.

Ishaq, I dan Noch, M. Tanpa tahun. Buah Kesemek: Potensi Sumberdaya Genetik Kabupaten Garut Jawa Barat. Lokakarya Nasional Pengelolaan dan Perlindungan Sumber Daya Genetik di Indonesia: Manfaat Ekonomi untuk Mewujudkan Ketahanan Nasional. Bandung (ID): Balai Pengkajian Teknologi Pertanian Jawa Barat. 108-118.

Kader, A.A dan Kitinoja, Lisa. 2003. Praktik-Praktik Penanganan Pascapanen Skala Kecil: Manual Untuk Produk Hortikultura. Edisi ke 4. Made, I. S, Utama, penerjemah. Bali (ID): Universitas Udayana kerjasama Direktorat Budidaya dan Pascapanen Buah Kementerian Pertanian. Terjemahan dari Small Scale
Postharvest Handling Practices: a Manual for Hprticultural Crops.

Kato, K. 1990. Astringency Removal and Ripening in Persimmons Treated with

Ethanol and Ethylene. Hortscience 25(2): 205-207.

Karhan, M., N. Artik, F. Özdemir. 2003. Changes of major Phenolic Compounds,

Major Caroenoids and L-Ascorbic Acid Composition Determined by HPLC in Persimmon (Diospyros kaki L.) During Ripening. GIDA 28 (4): 349-353.

Manganaris, G.A., M. Vasilakakis, G. Diamanditis, I. Mignani. 2007. The effect of postharvest calcium application on tissue calcium concentration,

quality attributes, incidence of flesh browning and cell wall physicochemical aspects of peach fruits. Food Chem. 100: 1385-1392

Nakano, R., E. Ogura, Y. Kubo, and A. Inaba. 2003. Ethylene Biosynthesis in

Detached Young Persimmon Fruit Is Initiated in Calyx and Modulated by

Water Loss from the Fruit. Plant Physiol. 131: 276-286.

NG. 1992. Disopyros kaki L.f. p154-157 dalam E.W.M.VRHEIJ and R.E.CORONEL (eds.). Plant Resources of South-East Asia 2: Edible Fruit and Nuts. Bogor (ID) PROSEA Foundation. $446 \mathrm{p}$.

Pantastico, E.B. 1986. Fisiologi pasca panen, penanganan dan pemanfaatan buah-buahan dan sayur-sayuran tropika dan sub tropika. Yogyakarta (ID): Universitas Gajah Mada 
Pecis, E., Akaron Levi, and Ruth Ben-Arie. 1986. Deastringency of Persimmon Fruit By Creating A Modified Atmosphere in Polyethylene Bags. Journal of Food Science 1041, Volume 51, No. 4. 4p.

Pitojo, S dan Puspita, H. N. 2007. Seri Budi Daya Kesemek. Yogyakarta (ID): Kanisius.

Testoni, A. 2002. Post-harvest and Processing of Persimmon Fruit in Bellini E. (Ed.), Giordani (Ed.). First Mediterranean Symposium on Persimmon. Zaragoza: CIHEAM. p. $53-70$

Widjanarko, S.B. 2012. Fisiologi dan

Teknologi Pascapanen. Malang (ID): UB 